last sentence casts any reproach at the ale-bibber. The meaning seems rather to be that he who buys ale pays for no waste material, except perhaps for the last few drops in the cup which he sprinkles on the ground as a libation to a long-forgotten pagan deity commemorated in the traditional expression, "A drop for the wold Heark !"

Such sayings as we find in this intriguing collection range over the whole gamut of rural experience, and are by no means confined to observations on seasons, weather, birds, beasts, crops, trees, and the like. The human element, for example, is evident in such sayings as, "One boy is a boy, two boys are half a boy, and three boys are no boy at all"- - a profound truth which holds in the laboratory as fully as in the field. Perhaps latter-day conditions will give rise to a similar saying in which the one, two and three boys are replaced by Greenwich time, summer time, and double summer time!

One final example, drawn from the reviewer's own experience, may be given as a masterpiece of terse expression. A Somerset farmer of the old school had seen listening silently to a discussion on strikes and strikers. His opinion was asked. He removed his pipe, and as the adjacent cider-cup rose to its appointed place he let fall the memorable judgment : "Ah ... Laziness idden wo'th much 'ithout 'tis well vollied !"

JoHN READ

\section{SCIENCE AND LIFE IN THE WORLD}

\section{Science and Life in the World}

The George Westinghouse Centennial Forum, May 16, 17 and 18, 1946. (Whittlesey House Publication.) Vol. 1: Science and Civilization; The Future of Atomic Energy. Pp. ix +152. 12s. 6d. Vol. 2: Transportation-a Measurement of Civilization; Light, Life and Man. Pp. ix+236. 12s. 6d. Vol. 3 : A Challenge to the World. Pp. ix +198 . 12s. $6 d$. (New York and London: McGraw-Hill Book Co., Inc., 1946.)

O May 16,17 and 18 of last year a significant gathering of men of science and leaders in the worlds of education and industry met at Pittsburgh to commemorate the hundredth anniversary of the birth of George Westinghouse, one of America's most renowned inventors and industrialists. Twenty-four prominent men in the field of science and technology were invited to participate in a notable symposium which summarized a great deal of our current scientific knowledge and pointed the way towards future research and development. A verbatim transcription of the addresses given on this occasion, together with illustrations including photographs of all the speakers, have been collected to make the three volumes r.sviewed here. As is to be expected, there is a wide rariety of style, treatment and informative content in the different discourses.

The proceedings of the first day opened with an address on scientific ethics by Prof. A. V. Hill, foreign secretary of the Royal Society, who provided the link between the diverse matters which were considered after this. His thesis was that "the conditions of survival of man as a biological species and of his civilization involve a totally new factor in biology, the use of organised reason and accumulated knowledge. It was that which made the various civilizations possible and its perversions helped at intervals to bring them to an end." He is followed by Dr. Isaiah Bowman, the president of Johns Hopkins University, who speaks on the social composition of scientific power, and together with Dr. V. Bush, whose subject is "Planning in Science", provides a useful outline of the social aspects and possibilities of science. The latter part of the first volume is devoted to atomic energy.

Prof. J. R. Oppenheimer, who was in charge of the Los Alamos laboratory where the first atomic bombs were made, is rather inhibited by the demands of security, though he has some useful things to say and speaks with.authority; whereas Prof. E. Fermi, who constructed the first atomic pile, is less restrained and gives an account of the development of the pile, of which those at Hanford produce energy in amounts comparable with that of the largest hydro-electric plants. The applications of the new atomic discoveries to biology and medicine are dealt with by Dr. E. Chamberlain; and Dr. Hugh S. Taylor of Princeton, who is perhaps best known in Britain for his catalytic phase-change method of separating heavy water, gives a short and simple statement of nuclear science in chemistry.

The first part of the second volume is concerned with the problems of transport, particularly from the American point of view. The scientific organisation of shipping, aviation and road transport is considered by various American experts in terms of economics, speed and convenience. The chapters should prove to be valuable to those who have to cope with the differing conditions in Great Britain and Europe; but of most interest to the sociologist and layman is C. F. Kettering's paper on "The New American Way of Life" due to the development and popularization of the automobile. The book concludes with an excellent section entitled "Light, Life and Man". The various papers deal with biological warfare, photosynthesis, genetics with particular reference to artificial mutants and the recent work on moulds and enzymes, and Dr. Linus Pauling's investigations on molecular architecture in relation to biological reactions.

The third volume is an interesting mixture which shifts kaleidoscopically from one topic to another. There is a verbatim report of a broadcast brains trust, "Science, Salvation or Destroyer of Mankind", in which Dr. Urey has much to say. Also, we find an illustrated 'conducted tour' of the Buhl Planetarium and Institute of Popular Science at Pittsburgh. Accounts are also given of demonstrations in micro. biology and crystallography using the optical apparatus at the same institution. There can be ne doubt that good optical aids are an asset to the effective teaching of 'background' science. There follows a description of a visit to the Mellon Institute with its research work in plastics, petroleum and metallurgy. The volume also includes a number of short papers on the future of science as an aid to mankind, and Karl Compton's address on science "as an assurance against aggression and depression". The book ends fittingly with a short biography of George Westinghouse (1846-1914) by L. M. Stark. A detailed account is given of his invention of the air brake and the development of the turbo-alternator in the United States.

It is to be hoped that many more symposia on the broader social and ethical aspects of science will be held in various parts of the world, and that they will be reported as effectively as is done in these three admirably produced books. W. L. SUMNER 